\title{
From chemotherapy to oncoviruses - modern methods of treatment in metastatic melanoma
}

\section{Od chemioterapii do onkowirusów - nowoczesne metody leczenia czerniaka przerzutowego}

\author{
Hanna H. Drobek', Beata S. Bergler-Czop², Bartosz Miziołek ${ }^{3}$ \\ ISilesian Medical University in Katowice, Poland \\ ${ }^{2}$ Department of Dermatology, Silesian Medical University, Andrzej Mielecki Independent Public Clinical Hospital in Katowice, Poland \\ 3Silesian Medical University, Andrzej Mielecki Independent Public Clinical Hospital in Katowice, Poland \\ IŚląski Uniwersytet Medyczny w Katowicach, Polska \\ ${ }^{2}$ Katedra i Klinika Dermatologii Śląskiego Uniwersytetu Medycznego, Samodzielny Publiczny Szpital Kliniczny im. Andrzeja Mielęckiego \\ w Katowicach, Polska \\ 3Śląski Uniwersytet Medyczny, Samodzielny Publiczny Szpital Kliniczny im. Andrzeja Mielęckiego w Katowicach, Polska
}

Dermatol Rev/Przegl Dermatol 2017, 104, 396-410 DOl: https://doi.org/10.5 | 14/dr.2017.69947

\author{
CORRESPONDING AUTHOR/ \\ ADRES DO KORESPONDENCJI: \\ Hanna H. Drobek \\ Silesian Medical University \\ Katowice, Poland \\ e-mail: hdrobek@op.pl
}

\begin{abstract}
Melanoma develops from neuroectodermal cells known as melanocytes. Recent studies have revealed an alarming increase in the annual incidence of this disease in Poland and worldwide. Although melanoma accounts for a small percentage of occurrences in comparison with all cancers, it develops rapidly, proceeding in a short time to the advanced stage of the disease; thus successful therapy of melanoma becomes the key solution. The early treatment dates back to dacarbazine, a cytostatic drug, giving a clinical response only in approximately $15 \%$ of patients. However, targeted molecular treatment and immunotherapy have been essential breakthroughs, including BRAF inhibitors and ipilimumab, announced recently as the discovery of the decade. Furthermore, later medical studies have led to surprising findings, a crucial example being oncolytic therapy which attenuated viruses. Talimogene (T-VEC) is the first drug of this kind approved in unresectable melanoma. Research on its therapeutic properties is still ongoing.
\end{abstract}

\section{STRESZCZENIE}

Czerniak wywodzi się z komórek neuroektodermalnych, znanych jako melanocyty. Ostatnie badania wskazują niepokojącą tendencję wzrostową rocznej liczby zachorowań w Polsce i na świecie. Mimo małego odsetka zachorowań na tle pozostałych nowotworów, czerniak rozwija się bardzo dynamicznie, co powoduje, że w krótkim czasie choroba osiąga zaawansowany stopień. Ważnym zagadnieniem staje się w tej sytuacji skuteczna terapia czerniaka. Początki leczenia sięgają dakarbazyny, leku cytotoksycznego, który pozwalał uzyskać odpowiedź kliniczną jedynie u ok. $15 \%$ chorych. Przełom stanowiły terapia molekularna oraz immunoterapia, gdzie głośno było o inhibitorach BRAF czy też ipilimumabie, niedawno ogłoszonym osiągnięciem dekady. Nauka wciąż zaskakuje nowymi osiągnięciami w medycynie, czego przykładem jest onkolityczna terapia atenuowanymi wirusami. Talimogen (T-VEC) jest pierwszym tego typu 
lekiem, zatwierdzonym w leczeniu nieoperacyjnego czerniaka. Wciąż trwają badania nad jego terapeutycznymi możliwościami.

Key words: melanoma, resistance, ipilimumab, BRAF inhibitors, talimogene. Słowa kluczowe: czerniak, oporność, ipilimumab, inhibitory BRAF, talimogen.

\section{INTRODUCTION}

Cutaneous melanoma is a malignant tumor which arises from the malignant transformation of melanocytes. Its incidence shows a growing tendency both in Poland and worldwide [1, 2]. Although melano$\mathrm{ma}$ is less common than other skin cancers $(4 \%$ of skin tumors), it is the main cause $(80 \%)$ of death in dermatology due to malignancies [2]. The standardized incidence rate for melanoma in Poland is 4.9/ 100000 , while in the United States it is estimated to be 21.8/100 000 men and women yearly $[1,3,4]$. The standardized mortality rate in Poland and the US is assessed at 1.7/100 000 and 2.7/100 000 men and women per year respectively [1, 3-5]. Clinical staging determines therapeutic management and has a strong impact on the survival of patients [4]. Table 1 compares the 5-year survival rates depending on the distribution of metastasis between Poland and the United States.

The aim of this publication is to sum up recent treatment options for metastatic melanoma. Both PubMed and the Scopus database were searched to review different interventions. From among 42 quoted publications 36 were released between 2012 and 2017.

\section{CHEMOTHERAPY}

Systemic treatment initially was based on alkylating agents. Dacarbazine (DTIC) was the first cytotoxic drug approved in monotherapy for metastatic melanoma. Dacarbazine demonstrated a clinical response in only $15-20 \%$ of patients $[1,2,6,7]$. According to the treatment protocol the drug is administered in-

\section{WPROWADZENIE}

Czerniak skóry jest nowotworem złośliwym powstającym w wyniku złośliwej transformacji melanocytów. Jego częstość występowania zarówno w Polsce, jak i na świecie ma tendencję wzrostową [1, 2]. Choć czerniak rozpoznawany jest rzadziej niż inne nowotwory złośliwe skóry (4\% przypadków nowotworów skóry), stanowi on główną przyczynę (80\%) zgonów u pacjentów dermatologicznych z powodu procesów nowotworowych [2]. W Polsce standaryzowany współczynnik zachorowalności wynosi 4,9/100 000, podczas gdy w Stanach Zjednoczonych jest on szacowany na 21,8/100 000 kobiet i mężczyzn rocznie $[1,3,4]$. Standaryzowane roczne współczynniki umieralności w Polsce i Stanach Zjednoczonych ocenia się odpowiednio na 1,7/100 000 i 2,7/100 000 kobiet i mężczyzn [1,3-5]. Stopień zaawansowania klinicznego określa postępowanie terapeutyczne i ma duży wpływ na przeżycie pacjentów [4]. W tabeli 1 zamieszczono porównanie wskaźników 5-letniej przeżywalności w zależności od lokalizacji przerzutów w Polsce i Stanach Zjednoczonych.

Celem niniejszej pracy jest podsumowanie najnowszych opcji terapeutycznych dostępnych w leczeniu czerniaka przerzutowego. W tym celu przeszukano bazy danych PubMed i Scopus. Spośród 42 cytowanych publikacji 36 wydano w latach 2012-2017.

\section{CHEMIOTERAPIA}

Początkowo stosowana terapia systemowa opierała się na lekach alkilujących. Dakarbazyna (dacarbazine - DTIC) była pierwszym lekiem cytotoksycznym dopuszczonym do stosowania $\mathrm{w}$ monoterapii $\mathrm{u}$ chorych na przerzutową postać czerniaka. Odpowiedź klinicz-

Table I. Five-year survival in Poland and the US

Tabela I. Pięcioletnie przeżycie w Polsce i w Stanach Zjednoczonych

\begin{tabular}{lcc}
$\begin{array}{l}\text { Distribution of melanoma/ } \\
\text { Lokalizacja czerniaka }\end{array}$ & Poland/Polska [2] & United States/Stany Zjednoczone [4] \\
\hline localized/postać zlokalizowana & $60-90 \%$ & $98.4 \%$ \\
\hline regional metastasis/przerzuty regionalne & $20-70 \%$ & $62.4 \%$ \\
\hline distant metastasis/przerzuty odległe & $5-10 \%$ & $17.9 \%$ \\
\hline
\end{tabular}


travenously in a daily dose of $200 \mathrm{mg} / \mathrm{m}^{2}$ (i.v.) for 5 consecutive days or in a weekly infusion of $850 \mathrm{mg} /$ $\mathrm{m}^{2}$ i.v. continued for 3 weeks $[1,6]$. An oral analogue of DTIC is temozolomide (TZM), which is given in a daily dose of $150-200 \mathrm{mg} / \mathrm{m}^{2}$ for 5 days every 4 weeks. This agent is indicated for the treatment of metastases to the central nervous system (CNS; monotherapy or radiochemotherapy) due to having better penetration through the blood-brain barrier than DTIC [6].

A phase III study with TZM $\left(200 \mathrm{mg} / \mathrm{m}^{2}\right.$ for 5 days within 28 days, 156 patients) and DTIC ( $250 \mathrm{mg} / \mathrm{m}^{2}$ for 5 days every 21 days, 149 patients) showed poor efficacy, and a response was observed in less than $15 \%$ of patients for both agents. The median survival (MS) for TZM was 7.7 months and 6.4 months for DTIC, but the difference was statistically insignificant. There was significantly $(p=0.012)$ longer progression-free survival (PFS; 1.9 months) for TZM than DTIC (1.5 months). Additionally, TZM had slightly less toxicity [8].

Another study compared the efficacy of monotherapy with DTIC and a combination with interferon (IFN). The meta-analysis demonstrated a significantly better overall response (OR) for DTIC with IFN compared with DTIC alone $(p<0.05)$. Although IFN combined with DTIC may improve the complete response rate, it increases the incidence of adverse events and has no significant effect on 1- and 3-year survival rates in cutaneous malignant melanoma [9].

Nowadays, chemotherapy should be limited to those cases with failure of molecular targeted treatment or immunotherapy [1].

\section{MOLECULAR TARGETED TREATMENT}

Taking into account the heterogeneous nature of malignant melanoma, a genetic approach is a valuable treatment option for distal metastasis. Molecular studies have identified numerous events which contribute to the malignant transformation of regular pigmentary cells. A series of DNA mutations are responsible for the development of abnormal karyotypes by activation of oncogenes (NRAS, BRAF, C-KIT, GNAQ, GNA11) and inactivation of suppressor genes (PTEN, p53). Mutations in the pathway RAS/RAF/MEK/ERK of mitogen-activated protein kinase (MAPK) occur in almost $75 \%$ of cases of melanomas [1, 2]. BRAF and NRAS are special targets for modern pharmacology and their activating mutations occur in $60-80 \%$ and $15-30 \%$ of melanomas, respectively $[1,2,10]$. In a meta-analysis of 36 studies of different melanoma subtypes, BRAF mutation was typical for SSMs (superficial spreading melanoma) and in those tumors arising on non-chronic ną na leczenie DTIC stwierdzono jedynie u 15-20\% pacjentów $[1,2,6,7]$. Zgodnie z protokołem leczenia lek podawany jest dożylnie (i.v.) w dawce $200 \mathrm{mg}$ / $\mathrm{m}^{2}$ p.c./dobę przez 5 dni lub w cotygodniowym wlewie $850 \mathrm{mg} / \mathrm{m}^{2}$ p.c. i.v. przez 3 tygodnie $[1,6]$. Doustnym analogiem DTIC jest temozolomid (TZM) podawany $\mathrm{w}$ dawce $150-200 \mathrm{mg} / \mathrm{m}^{2}$ p.c./ dobę przez $5 \mathrm{dni}$ co 4 tygodnie. Lek ten (stosowany w monoterapii lub $\mathrm{w}$ ramach radiochemioterapii) przeznaczony jest do leczenia pacjentów z przerzutami do ośrodkowego układu nerwowego (OUN) ze względu na fakt, że lepiej przenika przez barierę krew-mózg niż DTIC [6].

W badaniu III fazy dotyczącym TZM (200 mg/ $\mathrm{m}^{2}$ p.c. przez 5 dni w ciągu 28 dni, 156 pacjentów) i DTIC ( $250 \mathrm{mg} / \mathrm{m}^{2}$ p.c. przez 5 dni co $21 \mathrm{dni}, 149$ pacjentów) wykazano niewielką skuteczność, a odpowiedź stwierdzono u mniej niż 15\% pacjentów otrzymujących oba leki. Mediana czasu przeżycia dla TZM wyniosła 7,7 miesiąca, a dla DTIC 6,4 miesiąca, ale różnica nie była istotna statystycznie. Odnotowano istotną $(p=0,012)$ przewage TZM w postaci dłuższego czasu przeżycia bez progresji choroby (progression-free survival - PFS; 1,9 miesiąca) w porównaniu z DTIC (1,5 miesiąca). Dodatkowo wykazano nieco mniejszą toksyczność TZM [8].

W ramach innego badania porównano skuteczność monoterapii DTIC ze skojarzeniem DTIC z interferonem (IFN). Przeprowadzono metaanalizę, w której stwierdzono istotną przewagę $\mathrm{w}$ zakresie odpowiedzi całkowitej (overall response - OR) skojarzenia DTIC z IFN w porównaniu z DTIC w monoterapii $(p<0,05)$. Choć skojarzenie IFN z DTIC może skutkować wyższym odsetkiem odpowiedzi całkowitych, wiąże się ono $\mathrm{z}$ większą częstością występowania zdarzeń niepożądanych i nie ma istotnego wpływu na wskaźniki 1-rocznej i3-letniej przeżywalności u chorych na czerniaka skóry [9].

Obecnie stosowanie chemioterapii powinno być ograniczone do przypadków, w których leczenie ukierunkowane molekularnie lub immunoterapia zakończyły się niepowodzeniem [1].

\section{LECZENIE UKIERUNKOWANE MOLEKULARNIE}

Ze względu na zróżnicowanie postaci czerniaka podejście genetyczne stanowi cenną opcję terapeutyczną w przypadku przerzutów odległych. W badaniach molekularnych zidentyfikowano liczne zdarzenia, które przyczyniają się do transformacji złośliwej prawidłowych komórek pigmentowych. Za rozwój nieprawidłowych kariotypów odpowiada seria mutacji w DNA poprzez aktywację onkogenów (NRAS, BRAF, C-KIT, GNAQ, GNA11) oraz dezaktywację genów supresorowych (PTEN, p53). Mutacje w szlaku RAS/RAF/ MEK/ERK kinazy aktywowanej mitogenem (mitogen-activated protein kinase - MAPK) stwierdza się w niemal 75\% przypadków czerniaka [1, 2]. BRAF i NRAS są szczególnymi celami terapeutycznymi we współczes- 
sun-damaged skin. By contrast, NRAS mutation is more prevalent in nodular melanomas (NM) and those arising on non-chronic sun-damaged lesions [10]. The most common V600E modification is responsible for $74-90 \%$ of BRAF mutations and it is caused by replacement of valine by glutamine acid. An explanation for the high prevalence of V600E modification of BRAF is an increased tendency for interaction between hydrophobic valine and hydrophilic glutamine acid. Undoubtedly, BRAF mutation is not substantial and other changes within DNA (such as inactivation of p53) are needed for the malignant processes to proceed [1, 2, 11]. Genetic analysis of BRAF is advisable for all cases of melanoma at grade IIIc and IV [1].

Since 2011, the US Food and Drug Administration (FDA) has approved three drugs that disrupt hyperactivation of the MAPK pathway: the BRAF inhibitors (vemurafenib and dabrafenib) and the MEK inhibitor (trametinib). All three of them allowed for a significant improvement in overall and/ or progression-free survival in metastatic melanoma $[1,2,12]$.

In a phase III study comparing the efficacy of dacarbazine and vemurafenib, 675 patients with treatment-naive metastatic melanoma (positive BRAF V600 mutation) participated. Three hundred thirty-seven of them were treated with vemurafenib (960 mg orally, twice daily), whilst 338 patients were treated with dacarbazine $\left(1000 \mathrm{mg} / \mathrm{m}^{2}\right.$ i.v. every 3 weeks). Median follow-up was 12.5 months on vemurafenib and 9.5 months on dacarbazine. Median overall survival (OS) was significantly longer in the vemurafenib group than in the dacarbazine group (13.6 months vs. 9.7 months; $p=0.0008$ ), as was median PFS (6.9 months vs. 1.6 months; $p<0.0001)$ $[1,2,13]$.

Vemurafenib, representing the new generation of anti-tumor treatment, brings hope for a cure and prolongation of life, but can also severely decrease the quality of life because of its side effects. The treatment can be complicated by the development of secondary tumors or hyperkeratotic cutaneous lesions [14]. Other authors indicate even a greater risk of skin cancers and keratoacanthoma, which develop in almost $20 \%$ of treated patients within only a few weeks after initiating the treatment. These types of occurrences are prerequisites for complementary topical treatments, but do not require the discontinuation of vemurafenib [1, 14, 15].

A second BRAF inhibitor, dabrafenib, was approved in 2013 by the FDA for the treatment of metastatic melanoma with BRAF V600E mutation. The phase III trial recruited patients with stage IV or unresectable stage IIIC BRAF V600E melanoma, with no prior treatment. Patients were randomized nej farmakologii, a aktywujące mutacje w tych genach występują odpowiednio w $60-80 \%$ i $15-30 \%$ przypadków czerniaka $[1,2,10]$. W metaanalizie wyników 36 badań nad różnymi podtypami czerniaka wykazano, że mutacja w genie BRAF była typowa dla czerniaka szerzącego się powierzchownie (superficial spreading melanoma - SSM) oraz nowotworów rozwijających się na skórze nienarażonej na długotrwałe działanie promieni słonecznych. Mutacja w genie NRAS jest natomiast częstsza w przypadkach czerniaka guzkowego (nodular melanoma - NM) oraz nowotworów rozwijających się ze zmian na skórze narażonej na długotrwałe działanie promieni słonecznych [10]. Najczęstsza modyfikacja V600E odpowiada za 74-90\% mutacji w genie BRAF i polega na substytucji waliny przez kwas glutaminowy. Powodem dużej częstości występowania mutacji V600E w genie BRAF jest zwiększona tendencja do interakcji między hydrofobową waliną i hydrofilnym kwasem glutaminowym. Niewątpliwie mutacja w genie BRAF nie ma zasadniczego znaczenia i do rozwoju procesu nowotworowego konieczne są inne zmiany w DNA (takie jak dezaktywacja p53) [1, 2,11]. Analizę genetyczną BRAF zaleca się we wszystkich przypadkach czerniaka w stopniu IIIc i IV [1].

Od 2011 r. Amerykańska Agencja ds. Żywności i Leków (Food Drug Administration - FDA) zatwierdziła trzy leki, które hamują nadmierną aktywację szlaku sygnałowego kinazy MAP: inhibitory BRAF (wemurafenib i dabrafenib) oraz inhibitor MEK (trametynib). Wszystkie trzy umożliwiły uzyskanie istotnego wydłużenia czasu przeżycia całkowitego i/lub czasu przeżycia bez progresji choroby w czerniaku przerzutowym [1, 2, 12].

W ramach badania III fazy porównano skuteczność dakarbazyny i wemurafenibu. W badaniu wzięło udział 675 wcześniej nieleczonych chorych na czerniaka przerzutowego (dodatni status mutacji BRAF V600). Spośród nich 337 leczono wemurafenibem (960 mg doustnie 2 razy na dobę), a 338 pacjentów otrzymywało dakarbazynę (1000 mg/m² i.v. co 3 tygodnie). Mediana czasu obserwacji wynosiła 12,5 miesiąca w przypadku wemurafenibu i 9,5 miesiąca w przypadku dakarbazyny. Mediana czasu przeżycia całkowitego (overall survival - OS) była istotnie dłuższa w grupie przyjmującej wemurafenib w porównaniu z grupą stosującą dakarbazynę $(13,6$ vs 9,7 miesiąca; $p=0,0008)$; dotyczyło to również mediany PFS (6,9 vs 1,6 miesiąca; $p<0,0001)[1,2,13]$.

Wemurafenib, lek przeciwnowotworowy nowej generacji, daje nadzieję na wyleczenie i przedłużenie życia, ale ze względu na działania niepożądane może także obniżyć jakość życia pacjentów. Leczenie może być powikłane rozwojem nowotworu wtórnego lub rogowaceniem skóry [14]. Inni autorzy zwracają uwagę na większe ryzyko rozwoju raka i rogowiaka kolczystokomórkowego skóry, które występuje u niemal 20\% pacjentów w ciągu zaledwie kilku tygodni od rozpoczęcia terapii. Takie rozpoznanie stanowi wskazanie do 
to receive dabrafenib $150 \mathrm{mg}(n=187)$ or DTIC $(n=63)$ as $1000 \mathrm{mg} / \mathrm{m}^{2}$ every 3 weeks. The mean time of treatment was 5.1 months for dabrafenib and 2.1 months for DTIC. Therapy with dabrafenib appeared to be a more beneficial intervention with a longer PFS (6.7 months) than in those treated with DTIC (2.9 months) $[1,9,16]$.

BRAF activates MAPK/extracellular signal-regulated kinase 1 (MEK1) and MEK2 - which in turn activate downstream MAPKs - and regulates tumor cell proliferation and survival in many cancers, including melanoma. Trametinib, a highly selective allosteric inhibitor of MEK1 and MEK2 (MEKi), was approved by the FDA in 2013 for unresectable and metastatic melanoma (positive BRAF V600 mutation).

A phase III study evaluated the efficacy and safety of single-agent trametinib and chemotherapy (DTIC or paclitaxel). An intervention with trametinib (2 mg twice daily) was administered to 178 patients and 95 subjects received conventional chemotherapy based in DTIC or paclitaxel. Patients on chemotherapy could cross over to receive trametinib after disease progression that had been confirmed by an independent review. The primary efficacy population was patients with advanced/ metastatic BRAF V600E mutation-positive melanoma without a history of prior brain metastases. Trametinib reduced significantly $(p<0.0001)$ the risk of progression or death by $55 \%$ in comparison to chemotherapy (PFS 4.8 vs. 1.5 months). At 6 months, OS was $81 \%$ in the trametinib group and $67 \%$ in the chemotherapy group despite crossover $(p=0.01)$ $[1,2,17,18]$.

Unlike inhibitors of mutated BRAF, MEK inhibitors act non-selectively on all other cells of the body; hence side effects are more frequent (but less in comparison with DTIC). Besides predominant nausea, vomiting, fatigue and diarrhea, treatment with MEK inhibitors results in characteristic skin lesions (papulo-pustular rash or acne-like, changes in the seborrheic area) $[1,2,17]$.

Although this is a very effective strategy in melanoma treatment, most treated patients experience a relapse after a relatively short time. New treatment strategies which potentially prevent or overcome the emergence of drug resistance include a combination of inhibitors of the MAPK pathway with immunotherapy or with inhibitors of other aberrant cell signaling pathways common in melanoma [12].

Recent studies highlight the role of epigenetic dysregulation in the pathogenesis of melanoma. The bromodomain (BRD)-containing protein BRD4 (a part of the bromodomain and extraterminal domain (BET) family, including BRD2, BRD3, BRD4 and BRDT) plays an essential role in melanoma uzupełniającego leczenia miejscowego, ale nie wymaga odstawienia wemurafenibu [1, 14, 15].

Drugi inhibitor BRAF, dabrafenib, został zarejestrowany w 2013 r. przez FDA do stosowania w terapii czerniaka przerzutowego u pacjentów z mutacją BRAF V600E. Do udziału w badaniu III fazy włączono wcześniej nieleczonych pacjentów z czerniakiem w stopniu IV lub nieoperacyjnym czerniakiem w stopniu IIIC z mutacją BRAF V600E. Pacjentów poprzez randomizację przydzielono do grupy otrzymującej dabrafenib w dawce $150 \mathrm{mg}(n=187)$ lub DTIC w dawce $1000 \mathrm{mg} /$ $\mathrm{m}^{2}$ p.c. $(n=63)$ co 3 tygodnie. Średni czas leczenia wynosił 5,1 miesiąca w przypadku dabrafenibu i 2,1 miesiąca w przypadku DTIC. Stosowanie dabrafenibu wiązało się $\mathrm{z}$ większymi korzyściami terapeutycznymi w postaci dłuższego PFS (6,7 miesiąca) w porównaniu z DTIC (2,9 miesiąca) $[1,9,16]$.

BRAF aktywuje kinazę MAP/kinazy MEK1 i MEK2 regulowane sygnałami zewnątrzkomórkowymi, które z kolei aktywują kinazy MAP na dalszych etapach szlaku sygnałowego, oraz reguluje proliferację komórek nowotworowych w wielu typach raka, w tym czerniaku. Trametynib jest wysoce selektywnym, alosterycznym inhibitorem aktywacji i aktywności kinaz MEK1 i MEK2, zatwierdzonym przez FDA w 2013 r. do stosowania $\mathrm{w}$ terapii pacjentów $\mathrm{z}$ nieoperacyjnym czerniakiem lub czerniakiem z przerzutami (z mutacją genu BRAF V600).

W badaniu III fazy oceniano skuteczność i bezpieczeństwo stosowania trametynibu w monoterapii i chemioterapii (DTIC lub paklitaksel). Trametynib (2 mg 2 razy na dobę) podawano 178 pacjentom, a 95 pacjentów otrzymywało konwencjonalną chemioterapię opartą na DTIC lub paklitakselu. U pacjentów otrzymujących chemioterapię możliwa była zmiana leczenia na trametynib po stwierdzeniu progresji choroby potwierdzonej niezależną oceną. Populację do pierwszorzędowej analizy skuteczności stanowili pacjenci z zaawansowanym lub przerzutowym czerniakiem z mutacją BRAF V600E bez przerzutów do mózgu w wywiadzie. Trametynib wiązał się z istotnym $(p<0,0001)$ zmniejszeniem ryzyka progresji choroby lub zgonu o $55 \%$ w porównaniu $\mathrm{z}$ chemioterapią (PFS 4,8 vs 1,5 miesiąca). Po 6 miesiącach OS wynosiła $81 \%$ w grupie pacjentów przyjmujących trametynib i $67 \%$ w grupie stosujących chemioterapię mimo zmiany grupy leczenia $(p=0,01)[1,2,17,18]$.

W przeciwieństwie do inhibitorów BRAF inhibitory MEK nieselektywnie oddziałują na wszystkie inne komórki organizmu, dlatego ich działania niepożądane są częstsze (przynajmniej w porównaniu z DTIC). Oprócz najczęściej występujących nudności, wymiotów, zmęczenia i biegunki, terapia inhibitorami MEK powoduje wystąpienie charakterystycznych zmian skórnych (wysypki grudkowo-krostkowej lub trądzikopodobnych zmian na skórze łojotokowej) [1, 2, 17].

Choć jest to bardzo skuteczna terapia czerniaka, u większości pacjentów stosunkowo szybko dochodzi 
maintenance. The BRD is an approximately $110 \mathrm{ami}-$ no acid protein domain which recognizes acetylated lysine residues on the N-terminal tails of histones. Acetylation dynamics increase with DNA damage to regulate chromatin and BRD protein interactions that mediate key DNA damage response (DDR) activities. In cancer, DDR and acetylation pathways are disturbed $[12,19,20]$. JQ1 is a small molecule inhibitor that binds selectively to BET proteins to exert anti-tumor activity. JQ1 was shown to induce significant apoptosis in three different melanoma cells lines (A375, 451Lu, SK-MEL-28). Greater efficacy was also shown for combinations of JQ1 and vemurafenib, which induced significantly more intensive apoptosis in all three cell lines than each of the agents given alone [12].

Another interesting genetic dysregulation is microRNA-301a, which has been reported to act as an oncogene in different malignancies. Research by Schreuer et al. revealed upregulation of miR-301a in melanoma cells that correlated with metastasis and the poor prognosis of patients. Transfection with miR-301a/inhibitor allowed for significant inhibition of tumor growth. The study indicated that miR-301a may act as a potential target in treatment of malignant melanoma [21].

\section{ACQUISITION OF RESISTANCE IN GENERAL TREATMENT}

Unfortunately, the majority of patients who initially responded to either vemurafenib or dabrafenib developed resistance and relapsed within 6-12 months after discontinuation of treatment. Although treatment is combined with MEK inhibitors, the acquisition of resistance to BRAF inhibition is still proceeding; thus, prevention of resistance to vemurafenib and dabrafenib remains of special interest for modern pharmacology [1, 2, 22, 23].

Recent studies have shown that quantitative analysis of BRAF V600 mutant circulating cell-free tumor DNA (BRAF V600mut ctDNA) in plasma may have unique features as a monitoring tool during treatment with BRAF/MEK inhibitors. Two hundred forty-five plasma samples were derived from 36 enrolled patients. In 16 patients the plasma was acquired before the first dosing of dabrafenib/trametinib and a BRAF V600 mutation was detected in 12 of them at the baseline. BRAF V600mut ctDNA decreased rapidly upon initiation of anti-BRAF therapy, to be undetectable in $60 \%$ of patients $(n=7 / 12)$ at the sixth week of the pharmacological intervention. During the treatment, disease progression (PD) was diagnosed in 27 of 36 patients. An increase of the BRAF V600mut ctDNA copy number do nawrotu choroby. Nowe strategie terapeutyczne, które mogą zapobiegać rozwojowi oporności na lek lub pozwalają na jej przezwyciężenie, zakładają stosowanie skojarzenia inhibitorów szlaku sygnałowego kinazy MAP $\mathrm{z}$ immunoterapią lub $\mathrm{z}$ inhibitorami innych zaburzonych szlaków sygnałowych często obserwowanych w czerniaku [12].

Niedawne badania podkreślają rolę dysregulacji mechanizmów epigenetycznych w patogenezie czerniaka. Białko BRD4 zawierające bromodomenę (BRD), należące do podrodziny białek BET (bromodomain and extra-terminal domain), do której należą również BRD2, BRD3, BRD4 i BRDT, odgrywa istotną rolę w podtrzymaniu procesu nowotworowego w przebiegu czerniaka. BRD stanowi domenę białkową zbudowaną z ok. 110 aminokwasów, która wiąże się z resztami lizyny po acetylacji na N-terminalnych częściach histonów. Dynamika acetylacji wzrasta przy uszkodzeniu DNA w celu zapewnienia regulacji interakcji chromatyny i białka BRD, które działają jako mediatory kluczowej odpowiedzi na uszkodzenia DNA (DNA damage response - DDR). W przebiegu raka szlaki DDR i acetylacji ulegają zaburzeniu $[12,19,20]$. JQ1 jest drobnocząsteczkowym inhibitorem, który selektywnie wiąże się z białkami z podrodziny BET, wykazując działanie przeciwnowotworowe. Udowodniono, że JQ1 indukuje istotną apoptozę w trzech różnych liniach komórkowych czerniaka (A375, 451Lu, SK-MEL-28). Stwierdzono ponadto większą skuteczność w przypadku skojarzenia JQ1 i wemurafenibu, które w większym stopniu indukowało apoptozę we wszystkich trzech liniach komórkowych niż każdy z tych leków w monoterapii [12].

Inną interesującą kwestią jest deregulacja poziomu ekspresji miRNA-301a, która zgodnie z doniesieniami jest onkogenem w różnych nowotworach złośliwych. W badaniu Schreuera i wsp. wykazano, że nasilenie ekspresji miR-301a w komórkach czerniaka wiąże się z występowaniem przerzutów i niekorzystnym rokowaniem. Transfekcja inhibitorem miR-301a pozwoliła na uzyskanie istotnego zahamowania progresji nowotworu. W badaniu stwierdzono, że rolę potencjalnego celu leczenia czerniaka może odgrywać miR-301a [21].

\section{NABYWANIE OPORNOŚCI W LECZENIU OGÓLNYM}

Niestety u większości pacjentów, u których początkowo odnotowano odpowiedź na wemurafenib lub dabrafenib, stwierdzono rozwinięcie się oporności i nawrót choroby w ciągu 6-12 miesięcy od zakonczenia leczenia. Mimo stosowania terapii skojarzonej $\mathrm{z}$ inhibitorami MEK poziom nabywania oporności na inhibitory BRAF nadal się zwiększa, a możliwość zapobiegania wystąpieniu oporności na wemurafenib i dabrafenib stanowi przedmiot szczególnego zainteresowania współczesnej farmakologii [1, 2, 22, 23]. 
and fraction identified PD with sensitivity of $70 \%$ $(n=19 / 27)$ and specificity of $100 \%$. An increase in the BRAF V600mut ctDNA fraction was detected prior to clinical PD in $44 \%$ of cases $(n=12 / 27)$ and simultaneously with PD in $26 \%$ of patients $(n=7 / 27)$. Its potential role as an early predictor of acquired resistance requires further evaluation [24].

Tumor biopsies acquired from relapsed patients reveal the reactivation of MAPK, which is typically marked by excessive phosphorylation of ERK. The cyclin D-CDK4/6-INK4-Rb pathway (D-cyclin-dependent kinase 4/6-inhibitor of CDK4-retinoblastoma) regulates cellular proliferation by controlling the cell cycle checkpoint from G1 (pre-DNA synthesis) to S (DNA synthesis). Dysregulation of this pathway is frequently found in malignancies. Excessive phosphorylation of $\mathrm{Rb}$ proceeds to continuous growth in tumor cells. Recently, abemaciclib, a selective CDK4/ 6 inhibitor, was demonstrated to be a promising therapeutic agent for a vemurafenib-resistant A375 xenograft model [1, 2, 14, 21-23, 25, 26].

Furthermore, while a period of chronic vemurafenib therapy induces $\mathrm{pERK}$ elevation, temporary cessation of treatment allows for normalization of pERK, therefore enabling reintroduction of vemurafenib. However, all clinical evidence of the benefit of an intermittent schedule for BRAF inhibitors is restricted to only case series studies [22].

\section{IMMUNOTHERAPY}

Over the last several years targeted immunotherapy has become one of the most promising opportunities for patients with malignant melanoma. Tumor cells easily develop multiple resistance mechanisms so they may evade detection and a response from the immune system. However, immune system checkpoint inhibitors, which mediate the T-cell response, have shown a significantly enhanced antitumor response [27].

Ipilimumab is a human monoclonal antibody against cytotoxic T-lymphocyte antigen-4 (CTLA-4) that was approved by the FDA in 2011 and awarded with Prix Galien USA Discovery of the Decade in 2016, following its initial approval for unresectable or metastatic melanoma [25, 28, 29].

Immune responses are initiated by costimulatory interaction between CD28 and its primary ligands B7-1 (CD80) and B7-2 (CD86). CD28 is localized on $\mathrm{T}$ cells, whilst CD80 and CD86 are located on the surface of specialized antigen-presenting cells (APCs). CTLA-4 is a homolog of molecule CD28 and binds both B7-1 and B7-2 with affinities much greater than CD28. CTLA-4 downregulates T-cell activity by negative feedback in a specific immune response so as to avoid excessive intensity of the immunolog-
W ostatnich badaniach wykazano, że ilościowa analiza pozakomórkowego krążącego DNA nowotworu we krwi (circulating cell-free tumor DNA - ctDNA) z mutacją BRAF V600 w osoczu może stać się unikalnym narzędziem umożliwiającym monitorowanie terapii inhibitorami BRAF/MEK. Od 36 pacjentów włączonych do badania pobrano 245 próbek osocza. W przypadku 16 pacjentów osocze pobrano przed podaniem pierwszej dawki dabrafenibu lub trametynibu, a mutację BRAF V600 w punkcie początkowym stwierdzono u 12 z nich. Stężenie ctDNA z mutacją BRAF V600 gwałtownie się zmniejszyło po rozpoczęciu terapii inhibitorem BRAF do poziomu niewykrywalnego u $60 \%$ pacjentów $(n=7 / 12)$ po 6 tygodniach stosowania farmakoterapii. W trakcie leczenia progresję choroby (progressive disease - PD) stwierdzono u 27 spośród 36 pacjentów. Zwiększenie liczby kopii i stężenia frakcji ctDNA z mutacją BRAF V600 umożliwiło zidentyfikowanie PD z czułością wynoszącą 70\% ( $n=19 / 27)$ oraz swoistością $100 \%$. Wzrost stężenia frakcji ctDNA z mutacją BRAF V600 wykryto przed kliniczną PD w 44\% przypadków $(n=12 / 27)$, a jednocześnie z PD u $26 \%$ pacjentów $(n=7 / 27)$. Potencjalna rola wyników takiej analizy jako wczesnego czynnika prognostycznego nabytej oporności wymaga dalszych badań [24].

Biopsje guza u pacjentów z nawrotem choroby wykazały reaktywację MAPK, którą zazwyczaj cechuje nasilona fosforylacja ERK. Szlak sygnałowy cykliny D-CDK4/6-INK4-Rb (D-cyclin-dependent kinase 4/6-inhibitor of CDK4-retinoblastoma) reguluje proliferację komórek, oddziałując na punkty kontrolne cyklu komórkowego kontrolujące przejście z fazy G1 (przed syntezą DNA) do fazy S (synteza DNA). Zaburzenia tego szlaku są często obserwowane w przebiegu nowotworów złośliwych. Nasilona fosforylacja białka Rb przyczynia się do ciągłego wzrostu komórek nowotworowych. Ostatnio wykazano, że abemacyklib, selektywny inhibitor CDK4/6, jest obiecującym lekiem w przypadku modelu przeszczepu ksenogenicznego A375 opornego na wemurafenib [1, 2, 14, 21-23, 25, 26].

Ponadto, choć po okresie długotrwałej terapii wemurafenibem dochodzi do zwiększenia stężenia pERK, czasowe odstawienie leku pozwala na uzyskanie normalizacji stężenia pERK, co umożliwia ponowne włączenie wemurafenibu. Jednak dowody kliniczne na korzyści uzyskiwane dzięki stosowaniu schematu terapii przerywanej inhibitorami BRAF ograniczają się jedynie do opisów serii przypadków [22].

\section{IMMUNOTERAPIA}

W ciągu ostatnich kilku lat immunoterapia celowana stała się jedną z najbardziej obiecujących opcji terapeutycznych dla pacjentów z czerniakiem. Komórki nowotworowe z łatwością rozwijają liczne mechanizmy oporności, dzięki którym mogą uniknąć wykrycia i od- 
ical reaction. Ipilimumab inhibits CTLA-4, thereby allowing for appropriate T-cell activation through re-establishment of the costimulatory binding of CD28 to B7. This interaction restores T-cell proliferation and amplifies T-cell-mediated immunity, thus enhancing the patient's antitumor immune response $[25,30]$.

The efficacy of ipilimumab has been investigated in a phase III study. The research enrolled patients divided into 2 groups - previously treated (dose of ipilimumab - $3 \mathrm{mg} / \mathrm{kg}$ ), and with no prior therapy (ipilimumab $10 \mathrm{mg} / \mathrm{kg}$ in combination with DTIC). In the treatment-naive population median OS with ipilimumab $10 \mathrm{mg} / \mathrm{kg}$ plus DTIC was 11.2 months compared with DTIC in monotherapy (9.1 months, $p<0.001)$. In the previously treated patients, median OS with ipilimumab $3 \mathrm{mg} / \mathrm{kg}$ monotherapy was 10.1 months compared with the gp100 vaccine comparator (6.4 months, $p=0.003)$. The effect of ipilimumab on OS was observed independently of other factors such as age, sex or baseline serum lactate dehydrogenase levels. Importantly, survival curves separated and plateaued, suggesting that a proportion of patients experienced prolonged disease control. However, a dose of $10 \mathrm{mg} / \mathrm{kg}$ was associated with a higher frequency of adverse effects, such as nausea, vomiting, weight loss, decreased appetite, headache, pyrexia and insomnia $[1,15,25,28,29]$.

Clinical benefits are observed after 3-4 months, limiting its application to patients with advanced malignant melanoma and only minimal symptoms, good performance status, a slow course of disease and without concomitant autoimmune diseases. Due to frequent paradoxical progression of malignancy linked to infiltration of the tumor by immunologically active cells, especially at the beginning of treatment, a response should be assessed no earlier than after the first 12 weeks [1, 25].

Programmed cell death-1 (PD-1) receptor is another protein primarily located on the surface of activated immune cells. This receptor binds PD-L1 and PD-L1 proteins expressed on tumor cells, which exert inhibitory effects on T cells, B cells, NK cells and macrophages. Disruption of this unwanted interaction between PD-1 and PD-L1 leads to enhancement of anti-tumor responsiveness of the immune cells $[27,31]$.

Nivolumab is a human monoclonal immunoglobulin G4 (IgG4) PD-1 immune checkpoint inhibitor antibody which disrupts interactions between the PD-1 receptor and its ligands. The anti-PD-1 antibody was approved by the FDA in 2014 and awarded Prix Galien USA as the Best Biotechnological Product in 2015, following its approval for unresectable or metastatic melanoma (after treatment with ipilimumab and BRAF inhibitor) [27, 29, 31]. powiedzi ze strony systemu immunologicznego. Wykazano jednak, że stosowanie inhibitorów immunologicznych punktów kontrolnych regulujących odpowiedź, za którą odpowiadają limfocyty $\mathrm{T}$, wiązało się $\mathrm{z}$ istotnie lepszą odpowiedzią przeciwnowotworową [27].

Ipilimumab jest ludzkim przeciwciałem monoklonalnym przeciwko antygenowi 4 cytotoksycznych limfocytów T (cytotoxic T-lymphocyte antigen-4 - CTLA-4), który został zarejestrowany przez FDA w 2011 r., a po zatwierdzeniu do stosowania $\mathrm{w}$ leczeniu nieoperacyjnego lub przerzutowego czerniaka otrzymał nagrodę Prix Galien USA w kategorii Odkrycie Dekady w 2016 r. [25, 28, 29].

Odpowiedź układu immunologicznego inicjuje interakcję białka CD28 z jego podstawowymi ligandami B7-1 (CD80) i B7-2 (CD86), w wyniku której wysyłany jest sygnał kostymulujący. CD28 występuje na limfocytach T, podczas gdy CD80 i CD86 zlokalizowane są na powierzchni wyspecjalizowanych komórek prezentujących antygen (antigen-presenting cells - APC). CTLA-4 jest homologiem cząsteczki białka CD28 i wiąże się zarówno z cząsteczką B7-1, jak i B7-2, wykazując dużo wyższe powinowactwo niż CD28. CTLA-4 hamuje aktywność limfocytów T poprzez ujemne sprzężenie zwrotne w swoistej odpowiedzi immunologicznej, nie dopuszczając do jej nadmiernego rozwoju. Ipilimumab hamuje CTLA-4, co pozwala na odpowiednią aktywację limfocytów T przez ponowne ustanowienie kostymulującego wiązania CD28-B7. Interakcja ta przywraca proliferację limfocytów T i nasila odpowiedź immunologiczną, za którą odpowiadają te limfocyty, a przez to wzmacnia odpowiedź układu immunologicznego pacjenta na nowotwór [25, 30].

Skuteczność ipilimumabu oceniono w badaniu III fazy. W ramach tego badania pacjentów podzielono na 2 grupy - wcześniej leczonych (dawka ipilimumabu $3 \mathrm{mg} / \mathrm{kg}$ m.c.) oraz wcześniej nieleczonych (ipilimumab $10 \mathrm{mg} / \mathrm{kg}$ m.c. w skojarzeniu z DTIC). W populacji wcześniej nieleczonej mediana OS u pacjentów otrzymujących ipilimumab w dawce $10 \mathrm{mg} /$ kg m.c. w skojarzeniu z DTIC wynosiła 11,2 miesiąca w porównaniu z DTIC w monoterapii (9,1 miesiąca, $p<0,001)$. W grupie pacjentów uprzednio leczonych mediana OS u osób przyjmujących ipilimumab w dawce $3 \mathrm{mg} / \mathrm{kg}$ m.c. w monoterapii wynosiła 10,1 miesiąca $\mathrm{w}$ zestawieniu $\mathrm{z}$ lekiem porównawczym $\mathrm{w}$ postaci szczepionki peptydowej gp100 (6,4 miesiąca, $p=0,003)$. Wpływ ipilimumabu na OS obserwowano niezależnie od innych czynników, takich jak wiek, płeć czy wyjściowa aktywność dehydrogenazy mleczanowej. Co istotne, krzywe przeżywalności uległy rozdzieleniu i stabilizacji, co sugeruje, że u pewnej części pacjentów stwierdzono trwałą kontrolę choroby. Dawka $10 \mathrm{mg} /$ $\mathrm{kg}$ m.c. wiązała się jednak z większą częstością występowania działań niepożądanych, takich jak nudności, wymioty, utrata masy ciała, zmniejszenie łaknienia, ból głowy, gorączka i bezsenność [1, 15, 25, 28, 29]. 
The recommended dosage of nivolumab is $3 \mathrm{mg} /$ $\mathrm{kg}$ administered intravenously over 60 min every 2 weeks in monotherapy or combined with ipilimumab until disease progression or unacceptable toxicity. The most common adverse reactions are fatigue, decreased appetite, nausea, cough, dyspnea, pyrexia, headache and rash $[1,27]$.

A phase III study enrolled 945 patients and compared the efficacy of nivolumab in monotherapy $(n=316)$ with ipilimumab $(n=315)$, as well as combined $(n=314)$. Nivolumab was more effective than ipilimumab (PFS respectively 6.9 vs. 2.9 months), but the most effective was a combination of both therapies (PFS 11.5 months). This combined therapy appeared to be the most effective when expression of PD-L1 on melanoma cells was below $5 \%$. In cases of PD-L1 expression greater than 5\%, nivolumab treatment alone or given together with ipilimumab was comparable [1, 27, 32].

Tumor cells present immune escape mechanisms such as down-regulation of antigens to avoid an immune response. TETARs (CD8+ T-cells expressing two additional T-cell receptors) were generated to study tumor resistance immune reactions. Using RNA electroporation, cytotoxic T-cells were temporarily transfected with T-cell receptors (TCR). The first TCR is aimed at gp100, a protein which is a common melanoma antigen. The second TCR recognizes patient-specific, individual mutation of CCT6A (chaperonin containing TCP1, subunit $6 \mathrm{~A}$ ). These CD8+ T cells activate cytokine secretion and enhance lytic activity when they bind to target antigens on melanoma cells. The intended therapy would involve repeated injections of the RNA-transfected cells to overcome the transiency of TCR expression. In case of autoimmunity-related side effects, cessation of treatment would result in disappearance of the introduced receptors, which increases the safety of this management [33] (Table 2).

\section{ONCOLYTIC VIRAL THERAPY}

Molecular targeted therapy and immunotherapy provided a new approach for treatment of metastatic melanoma, but also triggered further expansions in therapeutic options. Oncolytic viruses were developed to provide a new management of malignancies [35]. They are defined as genetically engineered or naturally occurring viruses which were designed to replicate only in neoplastic cells, sparing normal ones [36].

Currently, there are two mechanisms of anti-tumor activity exerted by oncolytic viral therapy. Due to a natural predilection for cancer cells, oncolytic viruses are designed to replicate in tumor cells, contributing to a loss of their integrity and death.
Korzyści kliniczne obserwowano po 3-4 miesiącach, co ogranicza możliwość zastosowania terapii do pacjentów z zaawansowanym czerniakiem $\mathrm{i}$ jedynie minimalnymi objawami, $\mathrm{w}$ dobrym stanie ogólnym, $\mathrm{z}$ chorobą o wolnym przebiegu i bez wspótistniejących chorób autoimmunologicznych. Z powodu często występującej paradoksalnej progresji procesu złośliwego związanej z naciekaniem guza przez komórki immunokompetentne, zwłaszcza na początku terapii, odpowiedź należy ocenić nie wcześniej niż po 12 tygodniach $[1,25]$.

Receptor programowanej śmierci komórki 1 (programmed death receptor-1 - PD-1) jest kolejnym białkiem zlokalizowanym głównie na powierzchni aktywowanych komórek układu immunologicznego. Receptor ten wiąże się z PD-L1 i białkami PD-L1, do których ekspresji dochodzi na komórkach nowotworowych, hamując aktywność limfocytów T, limfocytów B, komórek NK i makrofagów. Przerwanie tej niepożądanej interakcji między PD-1 i PD-L1 prowadzi do nasilenia przeciwnowotworowej odpowiedzi komórek układu immunologicznego [27, 31].

Niwolumab jest ludzkim przeciwciałem monoklonalnym - immunoglobuliną G4 (IgG4) będącą inhibitorem punktu kontrolnego PD-1, która zaburza interakcje między receptorem PD-1 a jego ligandami. W 2014 r. FDA zarejestrowała to przeciwciało anty-PD-1. W 2015 r., po zatwierdzeniu do stosowania w leczeniu nieoperacyjnego lub przerzutowego czerniaka (po leczeniu ipilimumabem i inhibitorem BRAF), lek ten otrzymał nagrodę Prix Galien USA w kategorii Najlepszy Produkt Biotechnologiczny.

Zalecaną dawką niwolumabu jest $3 \mathrm{mg} / \mathrm{kg}$ m.c. podawane dożylnie $\mathrm{w}$ ciągu $60 \mathrm{~min}$ co 2 tygodnie w monoterapii lub w skojarzeniu z ipilimumabem do czasu stwierdzenia progresji choroby lub nieakceptowalnej toksyczności. Najczęstszymi działaniami niepożądanymi są: zmęczenie, zmniejszenie łaknienia, nudności, kaszel, duszności, gorączka, ból głowy i wysypka [1, 27].

Do udziału w badaniu III fazy włączono 945 pacjentów. Porównano w nim skuteczność niwolumabu w monoterapii $(n=316)$ ze skutecznością ipilimumabu $(n=315)$ oraz skojarzenia tych leków $(n=314)$. Stwierdzono większą skuteczność niwolumabu w porównaniu z ipilimumabem (PFS odpowiednio 6,9 vs 2,9 miesiąca), ale najskuteczniejsze okazało się skojarzenie obu leków (PFS 11,5 miesiąca). Skojarzenie leków było najlepszą opcją w przypadku obecności ekspresji PD-L1 w komórkach czerniaka poniżej $5 \%$. W przypadku ekspresji PD-L1 powyżej 5\% wyniki leczenia niwolumabem $\mathrm{w}$ monoterapii i w skojarzeniu $\mathrm{z}$ ipilimumabem były porównywalne [1, 27, 32].

Komórki nowotworowe rozwijają mechanizmy ucieczki przed odpowiedzią immunologiczną, $\mathrm{w}$ tym hamowanie ekspresji antygenów. W celu oceny oporności nowotworu na odpowiedź immunologiczną wygenerowano limfocyty T CD8+ z ekspresją dwóch 
Table 2. Summary of progression-free survival in therapies

Tabela 2. Podsumowanie przeżycia wolnego od progresji choroby dla poszczególnych terapii

\begin{tabular}{|c|c|c|c|}
\hline Study/Badanie & Treatment/Leczenie & Subjects/Pacjenci & PFS [months/miesiące] \\
\hline Middleton et al. (2000) [8] & dacarbazine/dakarbazyna & 149 & 1.5 \\
\hline Middleton et al. (2000) [8] & temozolomide/temozolomid & 156 & 1.9 \\
\hline McArthur et al. (20|4) [13] & vemurafenib/wemurafenib & 337 & 6.9 \\
\hline Hauschild A et al. (20।2) [34] & dabrafenib/dabrafenib & 187 & 6.7 \\
\hline Flaherty et al. (20|2) [18] & trametinib/trametynib & 178 & 4.8 \\
\hline Larkin et al. (20।5) [32] & ipilimumab/ipilimumab & 315 & 2.9 \\
\hline Larkin et al. (2015) [32] & nivolumab/niwolumab & 316 & 6.9 \\
\hline Larkin et al. (20 I 5) [32] & $\begin{array}{l}\text { ipilimumab + nivolumab/ } \\
\text { ipilimumab + niwolumab }\end{array}$ & 314 & 11.5 \\
\hline
\end{tabular}

PFS - progression-free survival/przeżycie wolne od progresji.

Secondly, tumor and viral antigens (such as damage-associated molecular patterns (DAMPs) and pathogen-associated molecular patterns (PAMPs)) are exposed after cell lysis to a host immune system, enhancing its tumor-specific response or inducing its anti-tumor activity. This second mechanism is of special interest because it allows for degradation of the neoplastic cells which are not even infected by the virus $[35,37]$.

Talimogene laherparepvec (T-VEC), attenuated herpes simplex virus of type 1 (HSV-1), is engineered to express granulocyte-macrophage colony-stimulating factor (GM-CSF) on tumor cells by insertion of the gene encoding human GM-CSF. This increases local production of GM-CSF, which recruits dendritic cells and macrophages into the tumor. Subsequently, those presenting cells activate a response of T-cells to melanoma cells. Deletion of two insignificant genes, infected cell protein 34.5 (ICP34.5) and ICP47, diminishes viral neuropathogenicity and promotes preferential replication within tumor cells [35-40] (Fig. 1).

The multicenter phase III OPTiM (Oncovex Pivotal Trial in Melanoma) study compared T-VEC with recombinant GM-SCF in 436 patients with unresectable stage IIIB, IIIC and IV melanoma. Subjects were randomized and received an intralesional injection of T-VEC (initial dose of $10^{6}$ plaque-forming units $(\mathrm{PFU}) / \mathrm{ml}$, followed 3 weeks later by $10^{8} \mathrm{PFU} / \mathrm{ml}$ and continued every 2 weeks for 12-18 months) or subcutaneous recombinant GM-CSF (125 $\mu \mathrm{g}$ daily for 14 days in a 28-day cycle for 12-18 months) $[35,37,40]$. More than half $(55 \%)$ of the patients had not received prior therapy at baseline [37]. T-VEC significantly improved the durable response rate (DRR), contrasting with GM-CSF (16.3\% vs. $2.1 \%$, respectively). The objective response rate (ORR) dodatkowych receptorów T. Cytotoksyczne limfocyty $\mathrm{T}$ zostały czasowo transfekowane receptorami limfocytów T (T-cell receptors - TCR) z wykorzystaniem elektropolacji RNA. Pierwszy TCR skierowany jest przeciwko gp100, białku, które jest częstym antygenem czerniaka. Drugi TCR rozpoznaje swoistą dla pacjenta indywidualną mutację CCT6A (białko opiekuńcze zawierające TCP1, podjednostkę 6A). Limfocyty T CD8+ aktywują wydzielanie cytokin i zwiększają aktywność lityczną, wiążąc się z antygenami na powierzchni komórek czerniaka. Terapia zakładałaby stosowanie wielokrotnych wstrzyknięć komórek z transfekowanym RNA, co pozwoli na przezwyciężenie czasowego charakteru ekspresji TCR. W przypadku wystąpienia działań niepożądanych związanych $\mathrm{z}$ reakcją immunologiczną przerwanie terapii skutkowałoby zaniknięciem wprowadzonych receptorów, co zwiększa bezpieczeństwo tego leczenia [33] (tab. 2).

\section{TERAPIA WIRUSAMI ONKOLITYCZNYMI}

Celowana terapia molekularna i immunoterapia stanowią nowe podejście do leczenia czerniaka przerzutowego, ale również przyczyniły się do dalszych postępów w zakresie opcji terapeutycznych. Wirusy onkolityczne opracowano w celu zapewnienia nowego leku do stosowania w nowotworach złośliwych [35]. Definiuje się je jako wirusy uzyskane metodą inżynierii genetycznej lub występujące naturalnie, które replikują się wyłącznie w komórkach nowotworowych, oszczędzając prawidłowe [36].

Obecnie terapia wirusami onkolitycznymi opiera się na dwóch mechanizmach działania przeciwnowotworowego. Z powodu naturalnej predylekcji do komórek nowotworowych wirusy onkolityczne replikują się w tych komórkach, przyczyniając się do utraty ich integralności i śmierci. Dodatkowo antygeny nowotworo- 


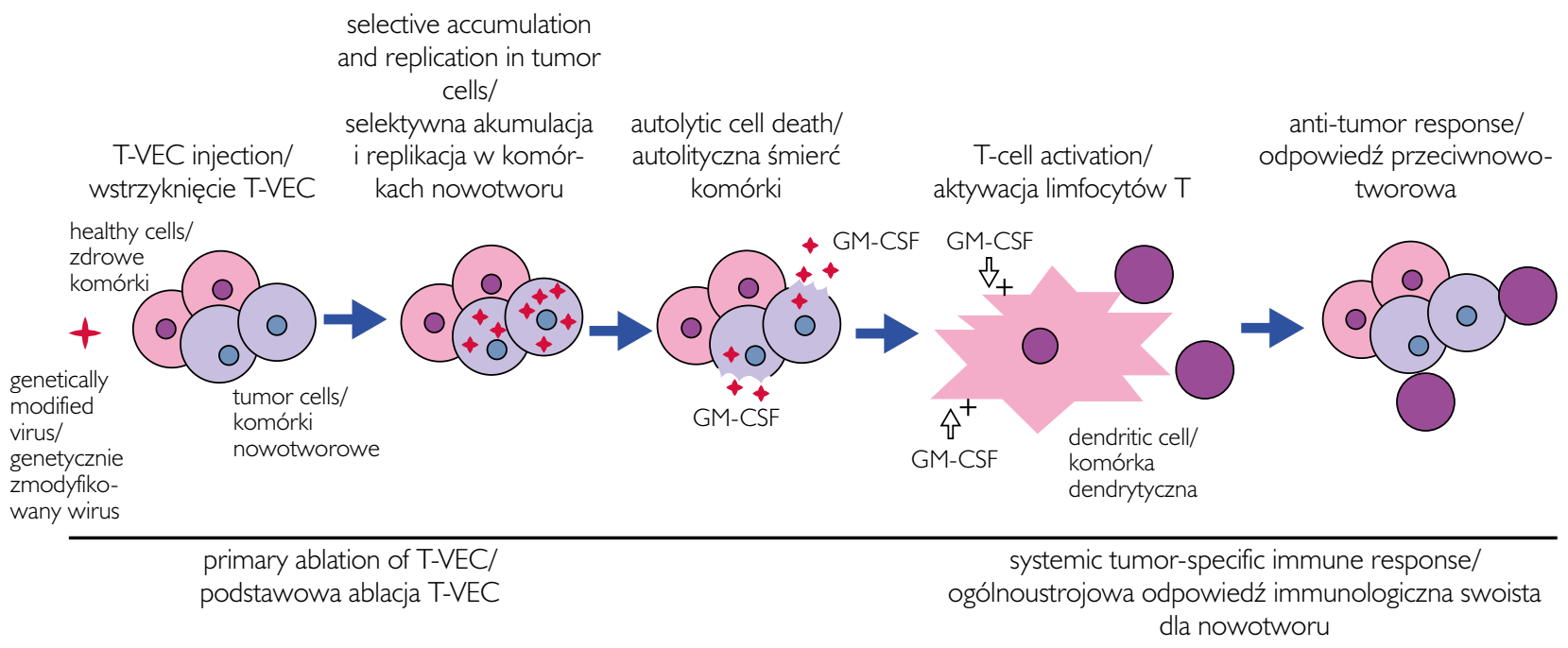

Figure I. Anti-tumor mechanism of T-VEC

Rycina I. Przeciwnowotworowy mechanizm działania T-VEC

was higher in the T-VEC arm (26\%) than the GMCSF arm (5.7\%). A response was observed in 15\% of visceral metastases (all uninjected). Median OS was 23.3 months in the T-VEC arm compared with 18.9 months in the control arm [35-37, 40].

The most common side effects reported by patients with T-VEC and GM-CSF therapy were fatigue $(50.9 \%$ vs. $36.8 \%$, respectively), chills $(49.7 \%$ vs. $7.9 \%)$, pyrexia $(39.9 \%$ vs. $10.5 \%)$, influenza-like illness $(33.7 \%$ vs. $9.2 \%)$ and nausea $(33.7 \%$ vs. $21.1 \%$ ). $8.6 \%$ of patients required early discontinuation of T-VEC treatment due to adverse effects [35, $37,40]$.

Based on the results of a phase III randomized study, talimogene laherparepvec (T-VEC), the first oncolytic immunotherapy, was approved by the FDA in October 2015, followed by the European Medicines Agency (EMA) in January 2016 and by Australia in May 2016, with its main indication for the local treatment of unresectable lesions in patients who have recurrent melanoma after initial surgery with cutaneous, subcutaneous, or nodal lesions (unresectable stage III or IVM1a, metastases spread either to the surrounding area or to other areas of the body but sparing bones, brain and lungs) [35-37, 41].

There have been the first attempts to combine T-VEC with other known therapeutic agents in metastatic melanoma. A multicenter phase Ib trial compared ipilimumab alone and combined with T-VEC. Nineteen patients were enrolled in this study to receive a combined therapy with T-VEC (initially $10^{6} \mathrm{PFU} / \mathrm{ml}$, then $10^{8} \mathrm{PFU} / \mathrm{ml}$ ) and ipilimumab $(3 \mathrm{mg} / \mathrm{kg})[38,39]$. The ORR was $41 \%$, with $24 \%$ complete response (CR), 18\% partial response (PR) and $35 \%$ with stable disease. Median time to re- we i wirusowe (takie jak wzorce molekularne związane $\mathrm{z}$ uszkodzeniem tkanki, damage-associated molecular patterns - DAMP, oraz wzorce molekularne związane z patogenami, pathogen associated molecular patterns - PAMP) wskutek lizy komórek są prezentowane układowi immunologicznemu gospodarza, co zwiększa odpowiedź swoistą dla guza lub indukuje działanie przeciwnowotworowe. Drugi z mechanizmów działania jest szczególnie interesujący, ponieważ pozwala na degradację komórek nowotworowych, które nawet nie zostały zakażone wirusem $[35,37]$.

Talimogene laherparepvec (T-VEC), atenuowany wirus opryszczki pospolitej typu 1 (HSV-1), został opracowany w celu stymulacji ekspresji czynnika stymulującego tworzenie kolonii granulocytów i makrofagów (granulocyte-macrophage colony-stimulating factor - GM-CSF) na komórkach nowotworowych przez wprowadzenie genu kodującego ludzki GM-CSF. Nasila to miejscowe wydzielanie GM-CSF, który rekrutuje komórki dendrytyczne i makrofagi do nowotworu. Następnie komórki prezentujące stymulują odpowiedź limfocytów T przeciwko komórkom czerniaka. Delecja dwóch nieistotnych genów, białek 34.5 (ICP34.5) i ICP47, zmniejsza neuropatogenne działanie wirusa i promuje preferencyjną replikację w komórkach nowotworu [35-40] (ryc. 1).

W ramach wieloośrodkowego badania klinicznego III fazy OPTiM (Oncovex Pivotal Trial in Melanoma, kluczowe badanie dotyczące stosowania produktu leczniczego OncoVEX w czerniaku) porównano T-VEC z rekombinowanym GM-SCF u 436 pacjentów $\mathrm{z}$ nieoperacyjnym czerniakiem $\mathrm{w}$ stopniu zaawansowania IIIB, IIIC i IV. Pacjentów poddano randomizacji do grupy otrzymującej wstrzyknięcia T-VEC w zmianę (dawka początkowa $10^{6}$ jednostek określających miano wirusa (PFU)/ml, a po 3 tygodniach $10^{8} \mathrm{PFU} /$ $\mathrm{ml}$, która to dawka była podawana co 2 tygodnie przez 
sponse was 2.9 months. Follow-up data noted an impressive ORR of $56 \%$ and DRR of $44 \%$. Survival at 12 and 18 months was $72.2 \%$ and $67 \%$, respectively. There was a $32 \%$ increase of side effects, which was assigned to ipilimumab [39].

MASTERKEY-265 was a phase Ib study of T-VEC (initially $10^{6} \mathrm{PFU} / \mathrm{ml}$, then $10^{8} \mathrm{PFU} / \mathrm{ml}$ ) and pembrolizumab (200 mg i.v.) for unresectable stage IIIBIV melanoma. The ORR was $48 \%$, with $14 \% \mathrm{CR}$. The side effects were more severe than with T-VEC and similar to those noted with pembrolizumab. A randomized phase III trial is in progress and compares combined therapy with pembrolizumab and T-VEC versus pembrolizumab and an intralesional placebo $[3,39,42]$.

T-VEC is now widely accepted as an option for treatment; however, its combination with various other agents in an effort to expand its use and synergize with other interventions is still being explored [39].

Oncolytic viral therapy is a promising treatment approach for malignancies, but its clinical implementation is strictly defined by the regulations of proper storage, preparation and administration. In addition, the special importance of biosafety, infection control and potential close contact transmission of the virus necessitates additional education and training for healthcare providers [35].

\section{CONCLUSIONS}

The preceding literature review notes the progress in treatment of melanoma, as well as its continuous need of further improvement. Taking into account the heterogeneous nature of melanoma, it is reasonable to apply combined therapies based on the co-administration of several agents. Unfortunately, some of them, such as vemurafenib or dabrafenib, easily develop resistance. Although therapy is combined with MEK inhibitors, the number of relapsed patients is still increasing. Thus, the prevention of resistance to both vemurafenib and dabrafenib remains especially promising management.

Tumor cells often involve multiple resistance mechanisms, which eventually avoid the host-tumor immune system. However, immune system checkpoint inhibitors significantly enhance the antitumor response.

Oncolytic viruses represent a novel class of drugs in which attenuated viral vectors are used for the treatment of cancer. Studies using T-VEC's therapeutic possibilities alone or combined with other agents are still needed.
12-18 miesięcy) lub wstrzyknięcia podskórne rekombinowanego GM-CSF (125 $\mu \mathrm{g} /$ dobę przez $14 \mathrm{dni}$ w cyklu 28-dniowym przez 12-18 miesięcy) [35, 37, 40]. $\mathrm{U}$ ponad połowy (55\%) pacjentów $\mathrm{w}$ punkcie początkowym odnotowano brak wcześniejszego leczenia [37]. Wykazano, że stosowanie T-VEC skutkowało istotną poprawą odsetka trwałych odpowiedzi (durable response rate - DRR), czego nie odnotowano $\mathrm{w}$ przypadku GM-CSF (odpowiednio 16,3\% vs 2,1\%). Odsetek obiektywnych odpowiedzi (objective response rate - ORR) byl wyższy w grupie T-VEC (26\%) w porównaniu z grupą GM-CSF (5,7\%). Stwierdzono odpowiedź w przypadku 15\% przerzutów do narządów wewnętrznych (we wszystkich przypadkach nie wykonano do nich wstrzyknięcia). Mediana OS wynosiła 23,3 miesiąca $\mathrm{w}$ grupie T-VEC $\mathrm{w}$ porównaniu z 18,9 miesiąca w grupie kontrolnej [35-37, 40].

Najczęściej zgłaszanymi przez pacjentów otrzymujących T-VEC i GM-CSF działaniami niepożądanymi były zmęczenie (odpowiednio $50,9 \%$ vs 36,8\%), dreszcze $(49,7 \%$ vs $7,9 \%)$, gorączka $(39,9 \%$ vs $10,5 \%)$, objawy grypopodobne $(33,7 \%$ vs $9,2 \%)$ i nudności $(33,7 \%$ vs $21,1 \%)$. W przypadku $8,6 \%$ pacjentów wymagane było wcześniejsze odstawienie T-VEC z powodu działań niepożądanych [35, 37, 40].

Na podstawie wyników randomizowanego badania III fazy T-VEC został dopuszczony do obrotu jako pierwsza immunoterapia onkolityczna w październiku 2015 r. przez FDA, a następnie w styczniu 2016 r. przez Europejską Agencję Leków (EMA) i urząd rejestracji leków w Australii w 2016 r. Podstawowym wskazaniem do stosowania jest miejscowe leczenie nieoperacyjnych zmian nowotworowych u pacjentów z nawrotowym czerniakiem po początkowej terapii operacyjnej, z zajęciem skóry, tkanki podskórnej lub węzłów chłonnych (nieoperacyjny czerniak w stadium III lub IVM1a z przerzutami regionalnymi lub odległymi, z wyjątkiem przerzutów do kości, mózgu i płuc) [35-37, 41].

Podjęto wstępne próby skojarzenia T-VEC z innymi znanymi lekami stosowanymi w czerniaku przerzutowym. W wieloośrodkowym badaniu fazy Ib porównano stosowanie ipilimumabu w monoterapii i w skojarzeniu z T-VEC. W ramach tego badania 19 pacjentów otrzymywało skojarzenie T-VEC (początkowo $10^{6} \mathrm{PFU} / \mathrm{ml}$, następnie $10^{8} \mathrm{PFU} / \mathrm{ml}$ ) i ipilimumabu (3 mg/kg m.c.) [38, 39]. ORR wyniósł $41 \%$, a odpowiedź całkowitą (complete response - CR) odnotowano u $24 \%$ pacjentów, odpowiedź częściową (partial response - PR) u $18 \%$, a stabilizację choroby u $35 \%$. Mediana czasu do uzyskania odpowiedzi wynosiła 2,9 miesiąca. Dane z obserwacji wskazują na imponujący wynik leczenia w zakresie ORR - 56\% oraz DRR - 44\%. Przeżywalność po 12 i 18 miesiącach wynosiła odpowiednio $72,2 \%$ i $67 \%$. Wzrosła liczba przypadków działań niepożądanych o 32\%, co przypisano ipilimumabowi [39]. 


\section{CONFLICT OF INTEREST}

The authors declare no conflict of interest.
MASTERKEY-265 było badaniem fazy Ib dotyczącym stosowania T-VEC (początkowo $10^{6} \mathrm{PFU} / \mathrm{ml}$, następnie $10^{8} \mathrm{PFU} / \mathrm{ml}$ ) i pembrolizumabu (200 mg i.v.) u pacjentów $\mathrm{z}$ nieoperacyjnym czerniakiem $\mathrm{w}$ stopniu zaawansowania IIIB-IV. ORR wyniósł $48 \%$, a CR odnotowano u $14 \%$ pacjentów. Działania niepożądane były cięższe niż w przypadku T-VEC i podobne do odnotowanych dla pembrolizumabu. Obecnie trwa randomizowane badanie III fazy prowadzone $\mathrm{w}$ celu porównania terapii skojarzonej pembrolizumabem i T-VEC z terapią pembrolizumabem i wstrzykiwanym do zmian placebo [3, 39, 42].

T-VEC jest obecnie ogólnie uznaną opcją terapeutyczną, jednak nadal badane są możliwości jego skojarzenia $\mathrm{z}$ różnymi innymi lekami w celu potencjalnego rozszerzenia zastosowań i uzyskania synergii z innymi terapiami [39].

Terapia onkolitycznymi wirusami jest obiecującym podejściem do leczenia nowotworów złośliwych, jednak jej kliniczne zastosowanie jest ściśle uzależnione od zapewnienia odpowiednich warunków przechowywania, przygotowania i podania leku. Ponadto szczególne względy bezpieczeństwa, procedury kontroli zakażeń i potencjalne przeniesienie wirusa przez bliski kontakt z pacjentem wymagają dodatkowego przeszkolenia pracowników ochrony zdrowia [35].

\section{WNIOSKI}

Niniejszy przegląd piśmiennictwa zwraca uwage na postępy w terapii czerniaka oraz ciągłą potrzebę dalszych udoskonaleń. Ze względu na zróżnicowaną naturę czerniaka uzasadnione jest stosowanie terapii skojarzonych z wykorzystaniem kilku leków. Niestety w przypadku niektórych $\mathrm{z}$ nich, takich jak wemurafenib lub dabrafenib, łatwo dochodzi do rozwoju oporności. Mimo skojarzenia terapii z inhibitorami MEK liczba pacjentów, u których dochodzi do nawrotu choroby, nieustannie wzrasta. W związku z tym profilaktyka i zwalczanie oporności na wemurafenib i dabrafenib mogą przynieść szczególnie korzystne rezultaty.

Komórki nowotworowe często rozwijają liczne mechanizmy oporności, które pozwalają im na uniknięcie odpowiedzi immunologicznej gospodarza. Wykazano jednak, że stosowanie inhibitorów immunologicznych punktów kontrolnych wiązało się z istotnie lepszą odpowiedzią przeciwnowotworową.

Wirusy onkolityczne stanowią nową grupę leków, w których wykorzystuje się atenuowane wektory wirusowe do leczenia nowotworów złośliwych. Potrzebne są dalsze badania dotyczące oceny możliwości terapeutycznych T-VEC $w$ monoterapii lub $w$ skojarzeniu $\mathrm{z}$ innymi lekami.

\section{KONFLIKT INTERESÓW}

Autorzy deklarują brak konfliktu interesów. 
References

Piśmiennictwo

1. Rutkowski P., Wysocki P.J., Nasierowska-Guttmejer A., Fijuth J., Kalinka-Warzocha E., Świtaj T., et al.: Czerniaki skóry zasady postępowania diagnostyczno-terapeutycznego w 2016 roku. Przegl Dermatol 2016, 103, 1-18.

2. Koseła H., Świtaj T., Rutkowski P.: Zastosowanie inhibitorów BRAF i MEK w terapii zaawansowanego czerniaka. Onkol Prakt Klin 2011, 7, 246-253.

3. Agarwala S.S.: The role of intralesional therapies in melanoma. Oncology (Williston Park) 2016, 30, 436-441.

4. Howlader N., Noone A.M., Krapcho M., Miller D., Bishop K., Kosary C.L., et al.: SEER Cancer Statistics Review, 1975-2014, National Cancer Institute. Bethesda, MD, https://seer.cancer.gov/csr/1975_2014/.

5. Didkowska J., Wojciechowska U., Zatoński W.: Prognozy zachorowalności i umieralności na nowotwory złośliwe w Polsce do 2025 roku. Krajowy Rejestr Nowotworów 2009, 39-43.

6. Skórzewska M., Stępak E., Polkowski W. P.: Stan obecny oraz perspektywy leczenia uogólnionego czerniaka. Nowotwory J Oncol 2011, 61, 367-379.

7. Mackiewicz J., Kwinta Ł.: Nowe terapie celowane stosowane u chorych na czerniaka uogólnionego. Współcz Onkol 2010, $14,15-22$.

8. Middleton M.R., Grob J.J., Aaronson N., Fierlbeck G., Tilgen W., Seiter S., et al.: Randomized phase III study of temozolomide versus dacarbazine in the treatment of patients with advanced metastatic malignant melanoma. J Clin Oncol 2000, 18, $158-166$.

9. Xin Y., Huang Q., Zhang P., Yang M., Hou X.Y., Tang J.Q., et al.: Meta-analysis of the safety and efficacy of interferon combined with dacarbazine versus dacarbazine alone in cutaneous malignant melanoma. Medicine 2016, 95, 1-8.

10. Sheen Y.S., Liao Y.H., Liau J.Y., Lin M.H., Hsieh Y.C., Jee S.H., et al.: Prevalence of BRAF and NRAS mutations in cutaneous melanoma patients in Taiwan. J Formos Med Assoc 2016, 115, 121-127.

11. Menzies A., Long G., Murali R.: Dabrafenib and its potential for the treatment of metastatic melanoma. Drug Des Devel Ther 2012, 6, 391-405.

12. Paoluzzi L., Hanniford D., Sokolova E., Osman I., Darvishian F., Wang J., et al.: BET and BRAF inhibitors act synergistically against BRAF-mutant melanoma. Cancer Med 2016, 5, 1183-1193.

13. McArthur G., Chapman P., Robert C., Larkin J., Haanen J.: Safety and efficacy of vemurafenib in BRAFV600E and BRAFV600K mutation-positive melanoma (BRIM-3): extended follow-up of a phase 3, randomised, open-label study. Lancet Oncol 2014, $15,323-332$

14. Ankudowicz A., Brzezicka-Ciach U., Wenska B.: Skórne działania niepożądane w trakcie leczenia czerniaka wemurafenibem. Przegl Dermatol 2015, 102, 221-226.

15. Kowalska M., Kowalik A., Góźdź S.: Dermatologiczne objawy uboczne w przebiegu chemioterapii i celowanej terapii przeciwnowotworowej. Przegl Dermatol 2016, 103, 127-138.

16. Shih V., ten Ham R. M., Bui C.T., Tran D.N., Ting J., Wilson L.: Targeted therapies compared to dacarbazine for treatment of BRAFV600E metastatic melanoma: a cost-effectiveness analysis. J Skin Cancer 2015, 2015, 505302.

17. Schadendorf D., Amonkar M.M., Milhem M., Grotzinger K., Demidov L.V., Rutkowski P., et al.: Functional and symptom impact of trametinib versus chemotherapy in BRAF V600E advanced or metastatic melanoma: quality-of-life analyses of the METRIC study. Ann Oncol 2014, 25, 700-706.

18. Flaherty K.T., Robert C., Hersey P., Nathan P., Garbe C., Milhem M., et al.: Improved survival with MEK inhibition in BRAF-mutated melanoma. N Engl J Med 2012, 367, 107-114.

19. Gong F., Chiu L.Y., Miller K.M.: Acetylation reader proteins: linking acetylation signaling to genome maintenance and cancer. PLOS Genetics 2016, 12, 1-23.

20. Finley A., Copeland R.A.: Small molecule control of chromatin remodeling. Chem Biol 2014, 21, 1196-1210.

21. Schreuer M., Meersseman G., Van Den Herrewegen S., Jansen Y., Chevolet I., Bott A., et al.: Quantitative assessment of BRAF V600 mutant circulating cell-free tumor DNA as a tool for therapeutic monitoring in metastatic melanoma patients treated with BRAF/MEK inhibitors. J Transl Med 2016, 14, 1-11.

22. Tate S., Burke T., Hartman D., Kulanthaivel P., Beckmann R., Cronier D.: Optimising the combination dosing strategy of abemaciclib and vemurafenib in BRAF-mutated melanoma xenograft tumours. Br J Cancer 2016, 114, 669-679.

23. Hamilton E., Infante J.: Targeting CDK4/ 6 in patients with cancer. Cancer Treat Rev 2016, 45, 129-138.

24. Cui L., Li Y., Lv X., Li J., Wang X., Lei Z., et al.: Expression of microRNA-301a and its functional roles in malignant melanoma. Cell Physiol Biochem 2016, 40, 230-244.

25. Olszanski A.J.: Current and future roles of targeted therapy and immunotherapy in advanced melanoma. J Manag Care Pharm 2014, 20, 346-56

26. Lo R.S.: Melanoma prognostics and personalized therapeutics at a crossroad. J Invest Dermatol 2013, 133, 292-295.

27. Guo L., Zhang H., Chen B.: Nivolumab as programmed death-1 (PD-1) inhibitor for targeted immunotherapy in tumor. J Cancer 2017, 8, 410-416.

28. Eggermont A.M.M., Suciu S., Testori A.: Ipilimumab adjuvant therapy in melanoma. N Engl J Med 2017, 376, 398-399.

29. Opdivo Prescribing Information. Opdivo U.S. Product Information. Last updated: September 2016. Princeton, NJ: Bristol-Myers Squibb Company.

30. Leach D.R., Krummel M.F., Allison J.P.: Enhancement of antitumor immunity by CTLA-4 blockade. Science 1996, 271, 17341736.

31. Force J., Salama A.: First-line treatment of metastatic melanoma: role of nivolumab. Immunotargets Ther 2017, 6, 1-10.

32. Larkin J., Chiarion-Sileni V., Gonzalez R., Grob J.J., Cowey C.L., Lao C.D., et al.: Combined nivolumab and ipilimumab or monotherapy in untreated melanoma. N Engl J Med 2015, 373, 23-34.

33. Hofflin S., Prommersberger S., Uslu U., Schuler G., Schmidt C., Lennerz V., et al.: Generation of CD8C T cells expressing two additional T-cell receptors (TETARs) for personalised melanoma therapy. Cancer Biol Ther 2015, 16, 1323-1331. 
34. Hauschild A., Grob J.J., Demidov L.V., Jouary T., Gutzmer R., Millward M., et al.: Dabrafenib in BRAF-mutated metastatic melanoma: a multicentre, open-label, phase 3 randomised controlled trial. Lancet 2012, 380, 358-365.

35. Rehman H., Silk A., Kane M., Kaufman H.: Into the clinic: Talimogene laherparepvec (T-VEC), a first-in-class intratumoral oncolytic viral therapy. J Immunother Cancer 2016, 4, 53.

36. Fukuhara H., Ino Y., Todo T.: Oncolytic virus therapy: a new era of cancer treatment at dawn. Cancer Sci 2016, 107, $1373-1379$.

37. Harrington K., Andtbacka R., Collichio F., Downey G., Chen L., Szabo Z., et al.: Efficacy and safety of talimogene laherparepvec versus granulocyte-macrophage colony-stimulating factor in patients with stage IIIB/Cand IVM1a melanoma: subanalysis of the Phase IIIOPTiM trial. Oncotargets Ther 2016, 9, 7081-7093.

38. Bilsland A., Spiliopoulou P., Evans J.: Virotherapy: cancer gene therapy at last? [version 1; referees: 2 approved]. F1000Research 2016, 5, 1-10.

39. Orloff M.: Spotlight on talimogene laherparepvec for the treatment of melanoma lesions in the skin and lymph nodes. Oncol Virother 2016, 5, 91-98.

40. Puzanov I., Milhem M., Minor D., Hamid O., Li A., Chen L., et al.: Talimogene laherparepvec in combination with ipilimumab in previously untreated, unresectable stage IIIB-IV melanoma. J Clin Oncol 2016, 34, 2619-2626.

41. First oncolytic immunotherapy medicine recommended for approval. Advanced therapy medicine Imlygic indicated to treat certain stages of melanoma. European Medicines Agency 2015, 692401.

42. Long G.V., Dummer R., Ribas A., Puzanov I., Michielin O., VanderWalde A., et al.: A phase I/III, multicenter, open-label trial of talimogene laherparepvec (T-VEC) in combination with pembrolizumab for the treatment of unresected, stage IIIb-IV melanoma (MASTERKEY-265). J Immunother Cancer 2015, 3 (Suppl 2), 181.

Received: 16.05 .2017

Accepted: 28.07 .2017

Otrzymano: $16.05 .2017 \mathrm{r}$

Zaakceptowano: 28.07.2017 r.

How to cite this article

Drobek H.H., Bergler-Czop B.S., Miziołek B.: From chemotherapy to oncoviruses - modern methods of treatment in metastatic melanoma. Dermatol Rev/Przegl Dermatol 2017, 104, 396-410. DOI: https:/ /doi.org/10.5114/dr.2017.69947. 